\title{
Tokoh Lintas Agama Merawat Kerukunan Umat (Belajar Multikultural Dari Kota Malang)
}

\author{
1M. Ikhwan \\ 1STAIN Teungku Dirundeng Meulaboh \\ Jl. Alue Peunyareng Ujong Tanoh Darat Meureubo Aceh Barat \\ E-mail: m.ikhwan@staindirundeng.ac.id
}

\begin{abstract}
This study explains the experience of interfaith leaders in realizing religious harmony in Malang. The theory will be used the idea of spiritual connection and the meaning of religious peace on sharia and human rights theory. This study uses a qualitative method with a phenomenological research approach. The research subject is an interfaith figure in Malang, who is incorporated in the Religious Harmony Forum (FKUB). The type of data presented is primary data from the results of in-depth interviews with the research subjects. The data that has been collected is analyzed in five stages, namely transcribing data as it is, reducing and eliminating data, classifying data, validating data, and making a description as a final report. The results of this study are twofold: The first, Malang City interfaith leaders are active in anticipating and resolving conflicts and maintaining religious harmony that has been created in various ways such as dialogue, silaturrahim and cooperation. The second, the interfaith leaders of Malang interpret religious harmony by mutual tolerance, mutual respect, and mutual freedom in terms of social and humanity but still in their faith by not uniting them.
\end{abstract}

Keywords: Religious Leaders, Interfaith, Harmony, Multiculturalism

\begin{abstract}
Abstrak
Penelitian in menjelaskan pengalaman tokoh lintas agama dalam mewujudkan kerukunan umat beragama di Kota Malang. Teori yang akan digunakan adalah teori kerukunan umat beragama, teori hukum islam dan hak asasi manusia. Penelitian ini menggunakan metode kualitatif dengan pendekatan penelitian fenomenologi. Subjek penelitiannya adalah tokoh lintas agama di Kota Malang yang tergabung di Forum Kerukunan Umat Beragama (FKUB). Jenis data yang disajikan adalah data primer dari hasil wawancara mendalam dengan para subjek penelitian. Data yang telah terkumpul dianalisis dengan lima tahapan yaitu mentranskrip data apa adanya, mereduksi dan mengeliminasi data, mengklasifikasi data, memvalidasi data, dan membuat deskripsi sebagai laporan akhir. Adapun hasil penelitian ini ada dua: Pertama, tokoh lintas agama Kota Malang aktif dalam mengantisipasi dan menyelesaiakan konflik serta memelihara kerukunan umat beragama yang sudah tercipta dengan berbagai cara seperti berdialog, silaturrahim dan gotong royong. Kedua, tokoh lintas agama Kota Malang memaknai kerukunan umat beragama dengan saling toleran, saling menghormati, dan saling memberi kebebasan dalam hal sosial dan kemanusiaan namun tetap dalam iman masing-masing dengan tidak menyatukannya.
\end{abstract}

Kata Kunci: Tokoh Agama, Lintas Iman, Kerukunan, Multikultural

CPalita: Journal of Social Religion Research. This is an open access article under the CC BY-SA 4.0 license (https://creativecommons.org/licenses/by-sa/4.0/). 


\section{Pendahuluan}

Kerukunan umat beragama sangat penting untuk dirawat dan dilestarikan, mengingat Indonesia yang luas terbentang dari Aceh hingga Papua memiliki keanekaragaman suku, budaya, ras, adat istiadat dan agama. Para pendiri bangsa (the funding fathers) telah meletakkan fondasi keanekaragman dengan sangat baik dalam semboyan "Bhineka Tunggal Ika" yang menggambarkan keanekaragaman masyarakat Indonesia suatu keniscayaan namun harus tetap dipelihara dalam bingkai Negara Kesatuan Republik Indonesia (NKRI).

Semboyan di atas harus diterjemahkan secara baik dalam berkehidupan kebangsaan, karena dalam beberapa laporan yang berkaitan dengan kerukunan beragama masih tercatat belum maksimal. Catatan Nawari dalam Koresy disampaikan bahwa pada masa reformasi konflik umat beragama tercatat sangat mencemaskan karena mencapai 73\%, meskipun melibatkan berbagai aspek seperti politik, kebijakan pemerintah, kesukuan, persoalan ekonomi dan pendidikan, serta yang terakhir penguatan identitas kedaerahan pasca otonomi daerah. ${ }^{1}$

Hasil survey yang disajikan oleh Freedom House melaporkan bahwa Indonesia pernah menempati peringkat negara "bebas" pada tahun 2013 sebagai bentuk kemajuan Indonesia dalam mengadvokasi Hak-hak Asasi manusia (HAM) dan perjalanan demokrasi yang membaik sejak reformasi 1998, namun prestasi ini tidak dapat dipertahankan selamanya, pada tahun 2014 Indonesia turun separuhnya menjadi negara "setengah bebas" dan terus terpuruk di tahun 2015 dengan posisi nilai empat dan menjadi dua pada tahun 2016. Bahkan pada tahun 2016 tersebut, Setara Institute memberi rapor merah bagi Indonesia dalam hal penegakan hak berekspresi dan beragama. $^{2}$

Laporan yang lain disampaikan Setara Institute tahun 2017 yang mengatakan keadaan beragama di Indonesia berangsur membaik dibandingkan tahun sebelumnya, meskipun Komisi Nasional Hak Asasi Manusia (Komnas HAM) masih merilis laporan tahunannya pada Januari 2017 masih memprihatinkan, lembaga tersebut melaporkan bahwa pengaduan terkait buruknya kondisi kerukunan umat beragama pada Januari hingga Desember 2016 berjumlah 97 pengaduan, jumlah ini meningkat dari jumlah pengaduan pada 2015 yang berjumlah 87 pengaduan. Adapun di

1 Stev Koresy Rumangit. "Kekerasan dan Diskriminasi antar Umat Beragama di Indonesia", Lex Administratum: Jurnal Elektronik Bagian Hukum Administrasi Negara Fakultas Hukum Unsrat, Volume 1, Nomor 2, 2013, 57.

2 Ali A Rizvi, Sang Muslim Ateis: Perjalanan dari Religi ke Akal Budi. (Jakarta: LSM Indeks, 2017), vii. 
tahun 2014 terdapat 76 kasus. Data ini menunjukan kenaikan yang signifikan terhadap kasus intoleransi beragama. ${ }^{3}$ Beberapa laporan yang dirilis di atas menunjukkan masih banyak pelanggaran hingga konflik yang terjadi di Indonesia dan perbedaan agama atau keyakinan yang tidak dirawat dapat menjadi salah satu akar permasalahannya.

Sekalipun demikian, masyarakat Indonesia masih dapat belajar pada daerah yang penikmatan dalam beragama dipenuhi secara memadai, salah satunya adalah Kota Malang. Kerukunan umat beragama di Kota Malang telah lama terjadi, hal itu dapat dilacak dalam sejarah Kota Malang tepatnya di desa Kauman yang kini masih berdiri kokoh rumah ibadah (Masjid dan Gereja) secara berdampingan. Sejarawan mengungkap bahwa Kauman sebagai salah satu desa di kecamatan Klojen Kota Malang. Kauman diyakini berasal dari kata "kaum" dan "iman" dan dimaknai sebagai perkampungan orang-orang beriman. ${ }^{4}$ Terlepas dari itu memang dulunya di daerah tersebut dihuni oleh umat muslim dan kristen yang mempunyai keyakinan masingmasing. Terdapat penginjilan dan juga kajian keagamaan Islam yang rutin dilaksanakan namun hal tersebut terjadi dalam bingkai toleransi. Hingga saat ini ibadah-ibadah dalam masing-masing agama tetap berjalan sebagaimana biasa tanpa ada hambatan apapun.

Kehidupan harmonis umat beragama merupakan suatu fenomena sosial yang nyata tercipta di Kota Malang, dibuktikan dengan beberapa penghargaan yang diperoleh terkait dengan jaminan kerukunan umat beragama. Misalnya penghargaan sebagai satu-satunya kota di Indonesia yang memebentuk Tim Pengendalian Keamanan dan Kenyamanan Lingkungan. ${ }^{5}$

Kota Malang juga diberikan penghargaan dalam prestasinya yang berhasil menjamin kerukunan umat beragama. Penghargaan ini diberikan oleh Forum Kerukunan Umat Beragama (FKUB) Jawa Timur tahun 2015.6 Selain itu, Kota Malang mendapatkan penghargaan dari KomNas-HAM lima kali berturut-turut yaitu 2015, 2016, $2017^{7}$ dan $2018^{8}$ serta $2019^{9}$ sebagai

\footnotetext{
3https://www.timesindonesia.co.id/read/news/140290/komnas-ham-kasusintoleransi-terus-meningkat

${ }^{4}$ Handianoto dan Soehargo, Paulus H. Perkembangan Kota dan Arsiterktur Kolonial di Malang.Surabaya-Yogyakarta (Lembaga Penelitian dan Pengabdian Kepada Masyarakat Univ. Kristen Petra dan Penerbit Andi, 1996), 19.

5https://suryamalang.tribunnews.com/2017/05/15/m-anton-kota-malangminiaturnya-indonesia-kami-menjaganya-supaya-tetap-damai-dan-rukun 6https://www.liputan6.com/regional/read/2575667/masjid-dan-gereja-bersandingmesra-di-malang ham/

${ }^{7}$ https://www.koran-jakarta.com/kota-malang--hattrick--raih-penghargaan-peduli-

${ }^{8}$ https://malangvoice.com/malang-raih-penghargaan-kota-peduli-ham-tahun-2018/
} 
kota peduli HAM termasuk di dalamnya pemeliharaan kerukunan beragama dan berkeyakinan

Kota Malang secara sebaran penduduk, merupakan kota yang dihuni masyarakat majemuk atau multikultural, semua agama ada di kota Malang. Menurut laporan Kemenag 2014 bahwa di Kota Malang terdapat 1.754.009, penduduk yang menganut agama Islam dan 51.765 menganut agama Kristen, sedangkan Katolik ada pada posisi ke tiga yaitu dengan jumlah 38.561, adapun yang menganut agama Budha berjumlah 17.243, Hindu menempati posisi ke empat dengan jumlah 9.621 dan yang terakhir adalah Konghucu yang hanya berjumlah 800 jiwa penganut. ${ }^{10}$

Kemajemukan tersebut terawat hingga saat ini dalam bingkai kerukunan tanpa konflik yang berarti. Masjid dan Gereja bersanding mesra di pusat kota ini menjadi bukti sejarah kerukunan beragama. Jamaah shalat Idul Fitri yang tidak tertampung di halaman masjid mengambil tempat di halaman gereja yang berdekatan, demikian juga sebaliknya saat natalan atau kegiatan keagamaan lainnya, mereka saling tolong-menolong dalam amal sosial kemanusiaan tanpa berprasangka buruk akan kehilangan agama dan iman. ${ }^{11}$

Suasana kerukunan antar umat beragama yang tercipta di Kota Malang melibatkan banyak pihak, dugaan penulis, tokoh lintas agama bertindak sebagai penentu dalam mewujudkan kerukunan umat beragama tersebut. Oleh karena itu, penelitian ini diajukan untuk memahami lebih mendalam bagaimana sesungguhnya yang terjadi. Penelitian ini difokuskan pada dua pertanyaan yaitu: Pertama, Bagaimana peran tokoh lintas agama dalam mewujudkan kerukunan umat beragama di Kota Malang? Kedua, Bagaimana makna kerukunan umat beragama dalam perspektif tokoh lintas agama Kota Malang ?

Penelitian ini diharapkan dapat memberi manfaat bagi berbagai pihak seperti akademisi, pemerintah, dan masyarakat. Bagi akademisi penelitian ini dapat menjadi tambahan referensi dan khazanah keilmuan khususnya yang memiliki minat kajian kerukunan umat beragama. Bagi pemerintah bisa menjadi salah satu rujukan dalam pengambilan sikap dan kebijakan umum (public policy) untuk menghindari timbulnya kekeliruan dalam menetapkan regulasi. Adapaun bagi masyarakat dapat menjadi bacaan untuk memahami pentingnya kerukunan umat beragama.

${ }^{9}$ https://bakesbangpol.malangkota.go.id/2019/12/11/kota-malang-raihpenghargaan-kota-peduli-ham-2019/

10 Kementrian Agama, "Laporan Tahunan Demografi Penganut Agama di Jawa Timur." Jakarta, 2014.

${ }^{11}$ https://www.tribunnews.com/regional/2015/07/18/di-kota-malang-toleransiantar-umat-beragama-telah-berlangsung-lama 
Jika ditelisik kajian terdahulu, diskursus kerukunan antar umat beragama sudah banyak disajikan. Diantaranya penelitian yang dilakukan oleh Kaharuddin dan Muh. Darwis, keduanya melakukan penelitian di Luwu Timur dengan dua kesimpulan: Pertama, masyarakat setempat sangat beragam dan majemuk baik itu suku, ras, budaya maupun agama, namun saling toleran. Kedua Forum Kerukunan Umat Beragama menjadi lembaga yang strategis dalam pemeliharaan kerukunan masyarakat dalam berbangsa dan bernegara khususnya dalam hubungan inter agama, antar agama, serta penganut agama dan pemerintah. ${ }^{12}$ Meskipun penelitian ini meneliti di FKUB namun lokusnya berbeda dengan yang disajikan dalam tulisan ini. Kemudian penelitian lain dilakukan oleh M. Tahriqul Huda dan Irma Khasanah, mereka meneliti tentang hubungan antar umat beragam pada suku Tengger di Pasuruan, Probolinggo dan Malang. Kesimpulannya adalah masyarakat dapat hidup berdampingan walaupun menganut keyakinan yang berbeda, hal ini diilhami oleh warisan budaya dan kearifan lokal yang dirawat dengan baik karena mempunyai nilai-nilai yang melampaui batas agama, suku, ras dan keyakinan sehingga masyarakat tetap harmoni dalam tatanan yang egaliter dan rasa persaudaraan. ${ }^{13}$ Tulisan ini melihat kerukunan dalam bingkai kebudayaan dan kearifan lokal.

Selanjutnya A. Sulaeman Rahmadi mengatakan bahwa kerukunan antarumat beragama tercipta dengan berpijak pada peraturan perundangan yang berlaku di Indonesia, selain itu menurutnya kerukunan umat beragama bukan berarti kebersamaan dalam suatu kegiatan, atau penyatuan keyakinan agama, tetapi suatu kehidupan berbangsa dan bernegara yang rukun, aman, damai, saling menghargai di antara semua umat beragama, yang berdasarkan atas kebenaran yang diyakini dan kemauan berdialog di antara mereka atas keyakinan tersebut agar terjalin keterbukaan warga masyarakat. ${ }^{14}$ Penelitian ini belum menyinggung peran tokoh lintas agama yang berperan dalam menciptakan, membina dan melestarikan kerukunan umat beragama itu.

Muhammad Anang Firdaus, hasil penelitiannya menjelaskan peran FKUB dalam membina kerukunan dengan cara melakukan dialog dengan pemuka agama dan tokoh masyarakat, menampung aspirasi kelompok keagamaan dan masyarakat, menyalurkan aspirasi masyarakat dengan

12 Kaharuddin dan Muh. Darwis, "Peran Forum Kerukunan Umat Beragama (FKUB) dalam Pembinaan Kerukunan Hidup Beragama di Luwu Timur", PALITA: Journal of SocialReligion Reseach, Volume 14, Nomor 1, 2019, 31.

${ }^{13}$ M. Thoriqul Huda dan Irma Khasanah, "Peran Budaya dalam Membangun Hubungan Antara Umat Beragama di Suku Tengger", PALITA: Journal of Social-Religion Reseach, Volume 14, Nomor 1, 2019, 13-14.

${ }^{14}$ A. Sulaeman Rahmadi, "Peran Kaum Muslimin Dalam Pembinaan Kerukunan Hidup Antarumat Beragama Di Kota Surakarta (Studi Di Fkub Kota Surakarta)”, Tesis: Universitas Muhammadiyah Surakarta, Maret 2012, 14. 
membuat rekomendasi sebagai bahan bagi pengambil kebijakan, melakukan sosialisasi peraturan perundang-undangan dan kebijakan terkait dengan kerukunan umat beragama dan pemberdayaan masyarakat, dan memberikan rekomendasi tertulis atas permohonan pendirian rumah ibadah. ${ }^{15}$ Penelitian ini difokuskan pada peran forum kerukunan umat beragama secara umum, bukan pada individu tokoh lintas agama yang dimaksud dalam penelitian ini.

Berikutnya adalah Ahmad Wahidi dalam penelitiannya memberi kesimpulan bahwa mistisisme sebagai jembatan menuju kerukunan umat beragama. Pendekatan ini diyakini sebagai bagian dari dimensi esoterik atau subtansi dari agama, karena dengan melihat subtansi dari agama akan dapat menghilangkan sekat-sekat yang membatasi masing-masing umat dari sisi hubungan sosial kemanusiaanya. ${ }^{16}$ Penelitian ini juga belum bersinggungan secara langsung karena melihat dari sudut pandang mistisme, tentu berbeda dengan peran tokoh agama yang dimaksud dalam penelitian ini.

Hasil penelitian lainnya disajikan oleh Umi Sumbulah, ia menemukan beberapa kesimpulan: Pertama, Tokoh lintas agama dalam memaknai pluralisme sangat variatif yaitu: toleransi, saling menghargai, tujuan semua agama sama, dan menyadari kenyataan bahwa terdapat banyak agama di dunia ini. Kedua, kerukunan umat beragama merupakan kondisi yang seimbang antara satu agama dengan agama lain, keragaman yang disadari, hak asasi manusia yang dihormati, serta kebaikan dan cinta kasih yang ditebarkan kepada sesama manusia. Ketiga, kerukunan umat beragama dapat diwujudkan melalui upaya-upaya internal dan eksternal. Secara internal penguatan keimanan masing-masing dan membangun kesadaran untuk mengembangkan sikap positif terhadap agama lain. Secara eksternal melalui dialog dan kerjasama untuk menyeleseaikan konflik keagamaan. Keempat, kerukunan beragama didukung oleh kesadaran untuk saling memahami dengan sikap-siakp yang positif. ${ }^{17}$ Penelitian ini melihat pandanganpandangan tokoh lintas agama terkait dengan pluralisme dan kerukunan, penelitian ini bersinggungan dan saling mendukung meskipun peneitian ini lebih fokus pada peran tokoh lintas agama dan makna kerukunan perspektif tokoh lintas agama tersebut. Sehingga dari kajian yang telah dilakuakan dianggap belum ada yang melihat lebih dalam dari peran tokoh lintas agama

15 Muhammad Anang Firdaus, "Eksistensi FKUB dalam Memelihara Kerukunan Umat Beragama di Indonesia”, Kontekstualita; Jurnal Penelitian Sosial Keagamaan, Volume 29, Nomor 1, 2014, 77.

16 Ahmad Wahidi, "Mistisisme Sebagai Jembatan Menuju Kerukunan Umat Beragama", Ulul Albab: Jurnal Studi Islam, Volume 14, Nomor 2, 2013, 145.

17 Umi Sumbulah, "Pluralisme dan Kerukunan Umat Beragama Perspektif Elit Agama di Kota Malang", Analisa: Journal of Social, Science and Religion, Volume 22, Nomor 1, 2015, 1. 
dalam memelihara kerukunan dan makna kerukunan umat beragama khususnya di Kota Malang.

Terkait peran tokoh agama, dapat dipinjam kerangka teoritis yang dikemukakan oleh Siti Aisyah dalam M. Ikhwan yang diawali dengan membagi peristilahan dalam teori peran kedalam empat golongan; Pertama, orang-orang yang mengambil bagian dalam interaksi sosial yang terdiri dari pelaku (actor) yang sedang berperilaku menuruti suatu peran tertentu dan target/sasaran yang mempunyai hubungan dengan aktor dan perilakunya. Teori peran dapat diterapkan untuk menganalisis setiap hubungan antara dua atau lebih (orang). Aktor menempati posisi pusat (fokal position), sedangkan target menempati posisi padanan dari pada pusat tersebut (counter position). Dengan demikian, target berperan sebagai pasangan bagi aktor. Hal ini terlihat sebagaimana dalam hubungan antara tokoh agama dan umat beragama yang saling menempati posisi tertentu seperti sebagai actor, focal position maupun counter position.

Kedua, perilaku yang muncul dalam interaksi, yaitu: 1) Expectation, harapan tentang peran adalah harapan-harapan orang lain tentang perilaku yang seyogyanya ditunjukkan oleh pemeran tertentu seperti tokoh agama yang harus memberikan nasihat-nasihat, perlindungan dan menciptakan kedamaian, bijaksana dan berbuat adil dalam mengambil keputusan dan lain sebagainya. 2) Norm, norma merupakan satu bentuk harapan yang dibagi menjadi dua yaitu harapan yang bersifat meramalkan sesuatu yang akan terjadi dan harapan normatif. 3) Performance, dalam hal ini peran tokoh agama yang dapat dilihat dari perilaku dan kiprahnya. 4) Evaluation and sanction. Mengenai penilaian dan sanksi didasarkan pada harapan masyarakat tentang norma. Berdasarkan norma orang memberikan kesan positif atau negatif terhadap suatu perilaku. Sanksi sebagai usaha untuk mempertahankan suatu nilai positif atau agar perwujudan peran diubah sedemikian rupa sehingga hal yang tadinya dinilai negatif bisa menjadi positif.

Ketiga, kedudukan orang-orang dalam perilaku. kedudukan (posisi) adalah kumpulan orang yang secara bersama (kolektif) diakui perbedaannya dari kelompok-kelompok yang lain berdasarkan sifat-sifat yang mereka miliki bersama, perilaku yang sama-sama mereka perbuat dan reaksi orangorang lain terhadap mereka.

Keempat, kaitan antara orang dan perilaku, kaitan (hubungan) yang dapat dibuktikan ada atau tidaknya dan dapat diperkirakan kekuatannya adalah kaitan antara orang dengan perilaku-perilaku yang mengambil bagian 
dalam interaksi (aktor). Dalam teori peran, aktor adalah penggerak atau pemimpin yang dalam penelitian ini adalah tokoh agama. ${ }^{18}$

Amanat Pasal 9 ayat (2) Peraturan Bersama Menteri Agama dan Menteri Dalam Negri Nomor 8 dan Nomor 9 tahun 2006 diuraikan bahwa tokoh agama yang tergabung dalam forum kerukunan umat beragama mempunyai beberapa tugas pokok secara umum yaitu Pertama, melakukan dialog dengan pemuka agama dan tokoh masyarakat; Kedua, menampung aspirasi ormas keagamaan dan aspirasi masyarakat; Ketiga, menyalurkan aspirasi ormas keagamaan dan masyarakat dalam bentuk rekomendasi sebagai bahan kebijakan pemerintah; Keempat, melakukan sosialisasi peraturan perundangundangan dan kebijakan dibidang keagamaan yang berkaitan dengan kerukunan umat beragama dan pemberdayaan masyarakat; Kelima, memberikan rekomendasi tertulis atas permohonan pendirian rumah ibadah. ${ }^{19}$

Pelaksanaan teknis peran tokoh agama dalam PBM di atas dijelaskan oleh Firdaus ${ }^{20}$ bahwa tugas melakukan dialog dengan pemuka agama dan tokoh masyarakat, menampung aspirasi dan menyalurkan aspirasi ormas keagamaan dan masyarakat dalam bentuk rekomendasi sebagai bahan kebijakan pemimpin pemerintahan di daerah propinsi, kabupaten atau kota, melakukan sosialisasi peraturan perundang-undangan dan kebijakan di bidang keagamaan yang berkaitan dengan kerukunan umat beragama dan pemberdayaan masyarakat dapat dilakukan dalam satu paket. Hal ini karena tugas-tugas tersebut saling terkait satu dengan yang lain dan saling berkesinambungan.

Kerukunan umat beragama mempunyai tiga bentuk yaitu: Pertama, kerukunan interumat beragama, kerukunan ini tercipta karena mencari persamaan untuk menghindari perpecahan antar mazhab dan aliran dalam satu agama tertentu. Kedua, kerukunan antar-umat beragama, hal ini dapat terjadi ketika umat antar-agama saling menghormati dan tidak saling mencurigai sesama dan yang terakhir adalah kerukunan umat beragama dengan pemerintah, kerukunan beragama sulit terjadi jika pemerintah dan umat beragama itu sendiri tidak saling bekerja sama membangun tatanan masyarakat madani (civil society). ${ }^{21}$ Menciptakan kerukunan beragama mempunyai beberapa unsur penting yang menjadi pra-syarat kerukunan

18 M. Ikhwan, Belajar Multikultural Dari Kota Malang. (Yogyakarta: Zahir Publishing, 2019), 39-41.

19 Titik Suwaryati, Imam Syaukani, Kompilasi Kebijakan dan Peraturan PerundangUndangan Kerukunan Umat Beragama. (Jakarta: Puslitbang Kehidupan Keagamaan, 2008), 42-46.

${ }^{20}$ Muhammad Anang Firdaus, "Eksistensi FKUB ..., 79.

21 M. Ikhwan, Belajar Multikultural ..., 29. 
tersebut seperti: menghargai pluralitas beragama, keadilan dan keterbukaan, sikap saling toleransi, dialog lintas agama, dan kerjasama dalam kehidupan sosial. $^{22}$

Adapun substansi kerukunan umat beragama itu ada lima. Pertama asimilasi, yaitu suatu keadaan dimana perbedaan menjadi saling diterima, baik terjadi satu arah atau dua arah perberbedaan sekaligus. Kedua integrasi, suatu tatanan kehidupan sosial yang seimbang tanpa menghilangkan diferensiasi namun melalui interaksi dan komunikasi yang intensif kohesif. Ketiga agree in disagreement, sikap yang menyetujui pada hal yang tidak disetujui artinya meskipun klaim kebenaran musti ada dalam setiap agama namun harus dibarengi dengan penghormatan pada agama lainnya. Keempat agree in agreement, yaitu sikap yang ditonjolkan menyetujui persamaan, manusia sama-sama berasal dari Adam dan Hawa, manusia juga mengakui bahwa tidak ada agama tanpa Tuhan, umat beragama tentu menyembah Tuhan sehingga dapat dimaknai bahwa menyembah Tuhan adalah semangat persatuan. Kelima agree in different, menyetujui perbedaan-perbadaan agama dan keyakinan karena perbedaan itu adalah sunnatullah yang harus dihormati. ${ }^{23}$

Kerukunan umat beragama merupakan dasar pijakan dalam pluralitas kehidupan agar hak dan kewajiban setiap orang dapat terpenuhi. Jirhanuddin menjelaskan bahwa ada beberapa makna kerukunan beragama secara umum yaitu meningkatkan ketakwaan umat, menciptakan stabilitas nasional, mensukseskan pembangunan bangsa, menciptakan kedamaian dalam bermasyarakat, memelihara rasa persaudaraan, menciptakan rasa aman, dan tidak ada konflik atas nama agama. ${ }^{24}$

Kerukunan beragama sangat identik dengan kebebasan beragama karena kebebasan menciptakan kerukunan umat, sehingga dalam bahasan ini diuraikan pandangan hukum islam tentang kebebasan beragama dan kaitannya dengan kerukunan beragama. Pada dasarnya setiap orang diberi kebebasan dan kemerdekaan melaksanakan ajaran agamanya. Dalam AlQur'an sebagai sumber hukum islam termaktub tiga bagian ayat-ayat yang berkaitan dengan kerukunan dan kebebasan beragama yaitu:

Pertama, ayat-ayat yang menyatakan bahwa setiap individu diberi kebebasan untuk memilih keimanan atau kekufuran dengan konsekuensinya masing-masing; Ayat-ayat tersebut seperti berikut ini: (Q.S. al-Baqarah, 2: 256). (Q.S. al-Kahf, 18: 29). (Q.S. al-Rûm, 30: 44-45). (Q.S. Yûnus, 10: 108 , al-

\footnotetext{
22 M. Ikhwan, Belajar Multikultural ..., 34.

${ }^{23}$ M. Ikhwan, Belajar Multikultural ..., 34-38.

24 Jirhanuddin, Perbandingan Agama Pengantar Studi Memahami Agama-Agama. (Yogyakarta: Pustaka Pelajar 2010), 193.
} 
Isrâ', 17: 15 dan Fâthir, 35: 39). Kedua, manusia tidak diberi celah untuk dapat memaksa setiap orang agar mengikuti agama tertentu kendatipun itu Nabi Muhammad Saw. beliau sebagai (basyiran wa nadziran) hanya sebagai penyampai ajaran Allah tentang kabar gembira dan peringatan. Beliau tidak memiliki hak memaksa orang lain untuk mengikuti agamanya, sebagaimana ayat-ayat berikut ini: (Q.S. al-Mâ'idah, 5: 99). (Q.S. al-Ra`d, 13: 40). (Q.S. Qâf, 50: 45). (Q.S. al-Syûrâ, 42: 6). (Q.S. Yûnus, 10: 41). Ketiga, memberikan petunjuk (hidayah) dan menyesatkan manusia hanya menjadi hak Allah Swt., bukan hak manusia termasuk Nabi Saw yang terdapat pada (Q.S. al-Baqarah, 2: 272). (Q.S. Yûnus, 10: 99-100). (Q.S. al-Qashash, 28: 56). ${ }^{25}$

Ayat-ayat tentang kebebasan beragama tersebut mengindikasikan betapa pentingnya membina kerukunan dengan umat lain dalam mengamalkan agama dan secara jelas Islam tidak mengabsahkan pemaksaan dalam memilih agama. Pemilihan agama diserahkan kepada masing-masing individu untuk memeluknya, dengan demikian kerukunan beragama dapat tercipta. Selain membaca pandangan al-Qur'an di atas juga dapat ditelisik dalam dokumen-dokuman hak asasi manusia Internasional maupun nasional.

Dalam dokumen Internasional ada Deklarasi Universal Hak Asasi Manusia (DUHAM) tahun 1948 pasal 2 dan pasal 18,26 Konvensi Internasional tentang Hak Sipil dan Politik tahun 1966 pasal 18, ${ }^{27}$ Konvensi Hak-hak Anak tahun 1989 pasal 14,28 dan Deklarasi PBB tentang Penghapusan segala Bentuk Diskriminasi Berdasarkan Agama dan Kepercayaan tahun 1981 Pasal 1, 2, 3, 4, 5, dan 6.29

Bebarapa peraturan di atas telah diratifikasi oleh banyak negara termasuk Indonesia sebagai itikad baik ikut dalam penyelenggaraan ketertiban dunia Internasional. Bahkan Indonesia juga telah meletakkan dasar-dasar perlindungan dan pemenuhan hak-hak asiasi manusia yang memadai terkait dengan kebebasan beragama sebagai syarat kerukunan beragama, hal ini dapat dilihat dalam Undang-Undang Dasar 1945 pasal 28E, 28I, 28J, 29.30 Serta Undang-Undang Nomor 39 tahun 1999 tentang Hak Asasi Manusia pasal 22 ayat (1) dan (2) dan pasal 24 ayat (1).

25 Dede Rodin, "Riddah dan Kebebasan Beragama Dalam Alquran”, Ahkam: Jurnal Ilmu Syariah, Volume 14, Nomor 2 Juli 2014, 255-256.

${ }^{26}$ Adnan Buyung Nasution, A. Patra M. Zen. Instrumen Internasional Pokok Hak Asasi Manusia. (Jakarta: Yayasan Obor Indonesia, 2006), 163.

${ }^{27}$ Adnan Buyung Nasution, A. Patra M. Zen. Instrumen Internasional ...,141.

${ }^{28}$ Adnan Buyung Nasution, A. Patra M. Zen. Instrumen Internasional ...,230.

${ }^{29}$ Adnan Buyung Nasution, A. Patra M. Zen. Instrumen Internasional ...,392-395.

30 Majelis Permusyawaratan Rakyat Republik Indonesia, Undang-Undang Dasar Negara Republik Indonesia Tahun 1945. (Jakarta: Sekretariat Jendral MPR RI, 2019), 156, 158, 160, 161. 


\section{Metode Penelitian}

Penelitian ini menggunakan metode kualitatif dengan pendekatan penelitian fenomenologi sebagai suatu konsep yang dikenal dengan Epoche ${ }^{31}$ Subjek penelitiannya adalah tokoh lintas agama yang ada di Kota Malang yang tergabung di FKUB Kota Malang dengan mempertimbangkan individu dan tempat untuk mendapatkan informasi yang cukup yang dapat dipelajari dan dipahami, yang biasa dikenal dengan purposive sampling.32 Jenis data yang akan disajikan adalah data primer dari hasil wawancara secara mendalam dengan para subjek penelitian. Data yang telah terkumpul dianalisis dengan logika berfikir induktif di mana silogisme dibangun berdasarkan hal-hal khusus atau data dari lapangan untuk mendapatkan kesimpulan yang dapat digunakan untuk membaca sesuatu hal secara umum. ${ }^{33}$ Tahapan analisa yang digunakan yaitu mentranskrip data apa adanya, mereduksi dan mengeliminasi data, mengklasifikasi data, memvalidasi data, dan membuat deskripsi sebagai laporan akhir. ${ }^{34}$

\section{Peran Tokoh Agama dan Konstruksi Makna Kerukunan Umat di Kota Malang}

Uraian tentang peran tokoh lintas agama dalam mewujudkan kerukunan umat beragama di Kota Malang dibagi kepada tiga bagian yaitu:

\section{Peran tokoh agama dan makna kerukunan dalam mengantisipasi konflik;}

Ida Bagus Bajera, tokoh agama Hindu mengatakan, peran tokoh agama sangatlah penting dalam mengantisipasi konflik umat beragama. Ada tiga peran yang utama yang dapat dilakoni sebagai tokoh agama:

"Pertama, dalam berpikir saya selalu berpikir positif terhadap orang lain, apapun dan bagaimanapun agamanya, sukunya, rasnya dan latar belakangnya. Kedua, dalam bertutur kata saya berkata yang baik, yang sopan, yang santun, jangan sampai menimbulkan orang lain itu tersinggung, sakit hati karena ucapan saya, dan Ketiga, dalam berperilaku sebagai tokoh agama saya berbuat yang baik, yang positif terhadap agama dan teman agama yang lain, sehingga mereka merasa

${ }^{31}$ Bertens, K. Sejarah Filsafat Kontemporer Jerman dan Inggris. (Jakarta: PT Gramedia Pustaka Utama, 2014), 148.

32 John Creswell, Perencanaan, Pelaksanaan, dan Evaluasi Riset Kualitatif dan Kuantitatif. (Yogyakarta: Pustaka Pelajar, 2015), 407.

33 Burhan Bungin, Metode Penelitian Kualitatif, Aktualisasi Metodologis ke Arah Ragam Varian Kontemporer. (Jakarta: Rajawali Press, 2011), 66.

${ }^{34}$ Asep Sudarsyah, "Kerangka Analisis Data Fenomenologi (contoh analisis teks sebuah catatan harian)", Jurnal Penelitian Pendidikan (JPP): Universitas Pendidikan Indonesia, 2016, 23. 
nyaman, merasa kondusif, tidak merasa terganggu ketika berada ditengah-tengah umat agama lain. Tiga hal di atas merupakan bagian dari ajaran agama Hindu yang saya imani tentang hubungan dengan umat lain (tri kaye sunde)."35

Beliau melanjutkan, sebagai tokoh agama Hindu, dalam berbagai kegiatan keagamaan, saya selalau menghadirkan tokoh agama lain, begitu juga sebaliknya saya tidak tertutup (ekslusif) terhadap agama lain, saya berusaha menghadiri undangan kegiatan (ceremonial keagamaan) dari agama lainnya. ${ }^{36}$

Pandangan Bajera di atas dikuatkan oleh Nugroho Sugiwijono sebagai tokoh agama Katolik yang diwawancarai secara terpisah. Menurutnya, peran tokoh agama dalam mengantisipasi konflik umat beragama itu adalah tidak mencampuri urusan agama lain, menghadiri kegiatan umat lain, belajar memahami agama lain, mencari titik kesamaan dan yang paling penting adalah meyakini ajaran agama masing-masing dengan seyakin-yakinnya, bukan menganggap semua agama itu sama, namun juga tidak mengatakan bahwa agama lain itu salah. ${ }^{37}$

Kerukunan selalu berbarengan dengan konflik, oleh karena itu konflik itu harus selalu dikelola dan diantisipasi sedini mungkin agar tidak muncul ke permukaan. Tokoh agama lainnya Stefanus Hadi Prayitno tokoh agama Kristen, beliau selalu bekerjasama dengan pihak-pihak terkait khususnya keamanan. ${ }^{38}$ M. Mujab tokoh agama Islam menambahkan, paling tidak ada dua hal yang beliau lakukan selaku tokoh agama dalam mengantisipasi konflik umat beragama di Kota Malang:

"Pertama, Bekerja sama dengan keamanan, pemerintah, intel dan pihakpihak terkait lainnya. Walaupun mungkin ada orang yang mengatakan bahwa kita terlalu represif, menggunakan pengawalan dari alat negara, guna menghindari hal yang tidak diinginkan tersebut, karena membagun kerukunan umat beragama perlu mengantisipasi konflik sedini mungkin, di manapun, kapanpun dan sejauh manapun. Misalnya menjaga kondisi pada hari-hari besar keagamaan, walaupun di tingkat masyarakat dan di tingkat komunitas tidak ada masalah, akan tetapi mungkin ada oknum yang melakukan suatu aksi brutal yang dapat

35 Pdt. Ida Bagus Bajera, wawancara oleh M. Ikhwan. Wawancara dengan Tokoh Agama Hindu Kota Malang (9 Februari 2018).

36 Pdt. Ida Bagus Bajera, wawancara ...,2018).

${ }^{37}$ Nugroho Sugiwijono, wawancara oleh M. Ikhwan. Wawancara dengan Tokoh Agama Katolik Kota Malang (13 Februari 2018).

38 Stefanus Hadi Prayitno, wawancara oleh M. Ikhwan. Wawanara dengan Tokoh Agama Kristen Kota Malang (4 Maret 2018). 
merugikan dan mencoreng nama baik komunitas, makanya sekecil apapun potensi koflik harus diantisipasi dan dikawal. Kedua, Meningkatkan faham keagamaan. Menururut saya faham agama dalam artian sebagai suatu akidah dan faham agama sebagai media atau pengetahuan dasar untuk bermuamalah musti dibedakan secara baik, sebab sering kali disuarakan dalam keadaan yang tidak tepat. Misalnya ada orang yang ceramah, "sesungguhnya agama yang banar itu agama Islam" hal ini dapat disampaikan dengan bahasa yang ramah "ini masalah keyakinan, bagimu agamamu dan bagiku agamaku". Jika disuarakan di publik luas dengan bahasa yang agitatif dan profokatif, itu akan melukai komunitas lain. Walaupun itu benar, tetap harus dengan hidmat, mengatakan begitu tidak harus dengan bahasa yang profokatif. Oleh karena itu tugas pokok tokoh agama itu adalah menyampaikan pesan agama itu dengan baik dan benar."39

Haroino tokoh agama Budha menambahkan bahwa dalam mengantisipasi konflik umat beragama di Kota Malang ini, semua tokoh agama sangat aktif. Saya selaku tokoh agama Budha misalnya, dalam berbagai kesempatan baik itu kegiatan intern agama Budha maupun kegiatan antar agama saya selalu mensosialisasikan kebijakan dan peraturan perundang-undangan yang berkaitan dengan kerukunan umat beragama hingga pada tingkat yang paling rendah Rukun Tetangga dan Rukun Warga (RT/RW). ${ }^{40}$

Hal yang sama juga disampaikan oleh Taufik Kususma selaku tokoh agama Islam. Ia mengatakan bahwa peran tokoh agama dalam mengantisipasi terjadinya konflik umat beragama itu dengan cara:

"membangun komunikasi yang baik, tidak membicarakan hal-hal yang sifatnya sensitif dan mengarah pada konflik di publik, untuk itu kami selaku tokoh agama selalu bertemu setiap hari Jum'at dan selalu berkoordinasi setiap saatnya apabila ada hal-hal yang dirasa penting dan sifatnya segera, sehingga konflik tidak terjadi, justru dengan itu tercipta rasa toleransi, saling menghargai, saling menghormati, saling pengertian dalam hidup bermasyarakat antar umat beragama." 41

\footnotetext{
${ }^{39}$ M. Mujab, wawancara oleh M. Ikhwan. Wawancara dengan Tokoh Agama Islam Kota Malang (10 Februari 2018).

${ }^{40}$ Hariono, wawancara oleh M. Ikhwan. Wawancara dengan Tokoh Agama Budha Kota Malang (11 Februari 2018).

41 Taufik Kususma, wawancara oleh M. Ikhwan. Wawancara dengan Tokoh Agama Islam Kota Malang (10 Februari 2018).
} 
Nursalim juga sebagai tokoh agama Islam memaparkan beberapa perannya sebagai tokoh agama dalam mengantisipasi konflik umat beragama di Kota Malang:

"Pertama, selalu menjaga kondisi agar tidak menimbulkan fitnah. Misal tidak mengikuti perayaan agama tertentu yang kira-kira dapat menimbulkan fitnah, sebab sebagaian umat beragama belum dapat menerima hal ini, sehingga selalu dimaklumkan agar tidak menjadi fitnah, demi menjaga hal ini saya lebih baik memilih tidak hadir di sana, tapi bukan berarti saya tidak berpartisipasi. Kedua, saya menyikapi halhal yang dikhwatirkan oleh umat dengan arif dan bijaksana, kadang ada masyarakat yang mengatakan ini mengkhawatirkan, sebagai tokoh agama kita tidak perlu terpancing suasana, kita memandang dari mana sudut yang menghawatirkannya, kalau memang menghawatirkan bagaimana menyikapinya, atas nama tokoh agama segera menanganinya, tentu dengan arif dan bijaksana itu tadi." 42

Senada dengan ini juga disampaikan Bintarto Mulyo selaku tokoh agama Khonghucu, dalam mengantisipasi konflik umat beragama ia selalu menjembatani hal-hal yang selama ini belum sinkron antar umat beragama dengan melakukan dua cara yaitu: Pertama menanamkan sifat ramah, sabar dan menahan diri tidak emosional, agar kita tidak terombang-ambing oleh keadaan. Kedua jangan menunjukan arogansi, menjelekkan agama lain dan mengatakan hanya agama saya yang paling baik, menurutnya agama itu hanya jalan menuju Tuhan, sehingga setiap orang ingin melalui jalan yang mana saja silahkan, dua hal ini penting karena pada tingkatan umat secara umum masih dipandang agak sulit dijalankan tuturnya. ${ }^{43}$

2. Peran tokoh agama dan makna kerukunan dalam menyelesaikan konflik;

Kota Malang yang kondusif ternyata bukan tidak ada konflik, namun konflik yang ada sesegera mungkin diselesaikan dengan cara-cara yang baik oleh para tokoh lintas agama. Konflik yang selama ini terjadi hanya pada tingkat yang rendah (terpendam) dan konflik tingkat sedang (lisan), sedangkan konflik pada tingkat tinggi (fisik) belum pernah terjadi karena berhasil diselesaikan secara baik pada tingkatan konflik sebelumnya.

"M. Mujab tokoh agama Islam mengatakan: "memang selama ini belum ada konflik agama yang berarti di Kota Malang. Potensi-potensi yang mengarah ke sana selalu segera ditangani. Beliau menambahkan dalam

\footnotetext{
42 Nursalim, wawancara oleh M. Ikhwan. Wawancara dengan Tokoh Agama Islam Kota Malang (13 Februari 2018).

43 Bintarto Mulyo, wawancara oleh M. Ikhwan. Wawanara dengan Tokoh Agama Konghucu Kota Malang (15 Februari 2018).
} 
menyelesaikannya dilakukan dengan beberapa hal yaitu Berdialog dan bermusyawarah, menghindari sikap hegemoni terhadap kelompok lain, dan tidak menonjolkan dominasi umat mayoritas, karena hal ini dipandang tidak perlu ditunjukkan, justru yang perlu ditunjukkan itu adalah sikap mengayomi dalam koridor dan etika. Kita selalu mengambil cara yang dipandang paling kondusif. Umat mayoritas menjadi barometer kerukunan itu."44

Penyelesaian konflik yang dilakuakan oleh tokoh agama berbagai macam cara. Nursalim, tokoh agama Islam mengatakan penyelesaian konflik dilakukan dengan:

"Pertama, berdialog antar tokoh agama khususnya yang ada di FKUB, jika konfliknya antar agama. Alhamdulillah masing-masing tokoh agama yang tergabung di FKUB adalah orang-orang yang memang betul-betul mempunyai wawasan, sehingga dalam dialog antar agama melahirkan berbagai solusi. Kedua, menyerahkan penyelesaian permasalahan kepada tokoh agama yang bersangkutan yang tergabung di FKUB maupun di luar FKUB, karena masing-masing tokoh agama bertanggung jawab atas umatnya masing-masing jika konfliknya dalam skala intern agama dan masih dapat diselesaikan secara intern agama. penyelesaikan konflik dengan cara kekeluargaan ini dilakuakan untuk menjaga keamanan, karena ketika terjadi konflik agama di sini walaupun kecil dapat saja diliput dan masuk berbagai media nasional bahkan internasional dan akan disaksikan oleh masyarakat dunia dan tentunya akan memberi kesan negatif untuk masyarakat dan dikhwatirkan dapat menyulut konflik selanjutnya."45

Hal ini juga disampaikan oleh Ida Bagus Bajera bahwa potensi yang mengarah pada konflik selalu diselesaikan secara kekeluargaan dengan musyawarah, mufakat, sehingga setiap masalah itu selalu menemui solusinya. ${ }^{46}$ Senada dengan itu juga dikatakan Nugroho sugiwijono bahwa menjalin komunikasi dengan sesama tokoh agama baik yang tergabung di FKUB maupun yang di luar FKUB merupakan jalan yang baik dalam menyelesaikan konflik antar maupun sesama agama. ${ }^{47}$ Dalam menyelesaiakan koflik kata Stefanus Hadi Prayitno: "kami berkoordinasi sesama tokoh agama maupun lintas agama. Konflik yang sudah terjadi biarlah menjadi pelajaran bagi semua termasuk yang tidak terlibat, pelajaran

\footnotetext{
${ }^{44}$ M. Mujab, wawancara ...,2018).

45 Nursalim, wawancara ..., 2018).

46 Pdt. Ida Bagus Bajera, wawancara ..., 2018).

47 Nugroho Sugiwijono, wawancara ..., 2018).
} 
dimaksud bukan untuk ditiru namun untuk dihindari masing-masing agama. ${ }^{48}$

3. Peran tokoh agama dan makna kerukunan dalam memelihara kerukunan umat beragama.

Kerukunan umat beragama yang telah berlangsung lama di Kota Malang merupakan suatu prestasi yang diupayakan untuk dipertahankan selamanya. Upaya yang dilakukan tokoh lintas agama dalam memelihara kerukunan tersebut seperti yang dikatakan M. Mujab :

"Selalu menunjukkan contoh yang baik (uswah hasanah) kepada publik bahwa kita hidup berdampingan dengan harmonis, gotong royong, memiliki solidaritas, dalam bingkai negara (nation), dari situ kemudian terbangun pola yang semulanya formal menjadi yang lebih personal. Misal ada yang sakit kita sambangi, kita jenguk, ada yang meninggal kita datangi keluarganya, ada yang punya hajat kita hadiri sepanjang tidak bertolak belakang dengan keyakinan masing-masing." 49

Hariono menambahkan, dalam memelihara kerukunan umat beragama kami selalu melakukan dialog sesama tokoh agama pada umumnya dan tokoh agama yang tergabung dalam FKUB khususnya, kami menerima dan menyalurkan aspirasi masyarakat yang sifatnya dapat memelihara kerukunan itu, dan kami memberikan rekomendasi terhadap ijin pendirian rumah ibadah yang telah memnuhi syarat dan ketentuan yang telah diatur dalam PBM. 50

Senada dengan itu juga disampaikan oleh Taufik Kusuma bahwa dialog tokoh inter dan antar-agama, menampung aspirasi masyarakat, menyalurkan aspirasi masyarakat, mensosialisasikan kebijakan dan perundang-undangan terkait dengan kerukunan dan memberikan rekomendasi terhadap ijin pendirian rumah ibadah bagi umat beragama yang telah memenuhi syarat dan ketentuan yang disepakati. ${ }^{51}$

Stefanus Hadi Prayitno sebagai tokoh agama Kristen mengatakan bahwa perannya selaku tokoh agama dalam mewujudkan dan memelihara kerukunan yaitu dengan mengajarkan paham agama kepada umat dengan sebaik-baiknya, karena beliau yakin tidak satupun agama yang mengajarkan konflik atau anti kedamaian. ${ }^{52}$

Kerukunan umat beragama mempunyai makna atau arti yang sangat luas dalam perspektif tokoh lintas agama. Setiap tokoh agama dalam

\footnotetext{
48 Stefanus Hadi Prayitno, wawancara ..., 2018).

${ }^{49}$ M. Mujab, wawancara ..., 2018).

${ }^{50}$ Hariono, wawancara ..., 2018).

51 Taufik Kusuma, wawancara ..., 2018).

52 Stefanus Hadi Prayitno, wawancara ..., 2018).
} 
memaknai kerukunan mempunyai perbedaan, makna yang mereka berikan itu saling melengkapi satu dengan yang lainnya seperti saling menghormati, saling toleran, saling memahami, saling pengertian, saling tanpa kecurigaan, saling menghargai, tidak ada konflik, damai, harmonis, tenang, nyaman dan tenggang rasa, tidak memaksakan kehendak, tidak mencampuri iman agama lain.

Dari penelitian yang telah dilakukan, penting untuk didiskusikan agar sampai pada kesimpulan-kesimpulan yang dapat dipahami. Peran yang dilakukan tokoh lintas agama Kota Malang tergambarkan seperti teori peran yang diajukan oleh Aisyah dalam M. Ikhwan di mana tokoh agama mengambil peran dalam interaksi sosial sebagai aktor dalam setiap tindakannya dan umat sebagai padanannya, antara dua komponen ini saling memengaruhi. Tokoh agama yang akur, aman, damai, dan rukun akan berdampak pada umat agama masing-masing. Sebagai tokoh agama diharapkan berperilaku sebagaimana harapan umat agama itu sendiri, seperti menyampaikan nasihat-nasihat, memberikan perlindungan, menciptakan kedamaian, bijaksana dan adil. 53

Selain peran tokoh lintas agama yang maksimal dalam mewujudkan kerukunan umat beragama sejalan dengan regulasi yang ada. Jika dikaitkan dengan kebijakan dan peraturan perundang-undangan yang berlaku dan atau yang diadopsi oleh Indonesia, maka akan ditemukan PBM menteri agama dan menteri dalam negeri nomor 8 dan 9 tahun 2006, pasal 28E, 28I, 28J, dan pasal 29 UUD 1945, UU nomor 39 tahun 1999 tentang HAM, Pasal 18 UU nomor 12 tahun 2005 tentang pengesahan konvenan sosial dan politok (SIPOL). Dalam beberapa aturan tersebut jelas disebutkan bahwa saling menghormati antar-agama (kebebasan beragama) merupakan kewajiban yang tidak dapat ditunda pelaksanaannya agar setiap agama dapat bebas mengekpresikan keagamaannya, tentu dengan tidak melanggar hak agama lain.

Sedangkan dalam syariah sebagai sumber ajaran agama Islam juga sangat banyak anjuran tentang kerukunan, kedamaian, kebebasan dalam beragama sesperti yang telah disebutkan dalam uraian teoritik di atas. Urusan agama adalah urusan individu, tidak ada yang bisa dicampuri apalagi diintervensi, dalam hal ini dikembalikan pada qaidah "bagimu agamamu bagiku agamaku".

Tokoh lintas agama Kota Malang memaknai kerukunan umat beragama itu dengan sangat beragam, seperti toleransi, saling memahami, saling

${ }^{53}$ Siti Aisyah, "Peran Tokoh Agama dalam Membina Kerukunan antar Umat Beragama Di Kawasan Pacinan Kota Semarang." Skripsi: Fakultas Ushuluddin Institut Agama Islam Negeri Walisongo, 2014. 
menghormati, saling menghargai, tidak ada konflik, damai, harmonis, tenang, nyaman dan tenggang rasa, sebagai suatu capaian dari kebersamaan dalam perbedaan (pluralitas), tidak mengganggu dan mencemooh umat dan atau agama lain dalam melaksanakan aktifitas keagamaan masing-masing, dan tidak memaksakan kehendak.

Pemahaman terhadap makna kerukunan umat beragama ini menjadi penting, karena semakin luas pemahaman makna kerukunan itu maka semakin luas pula cakupan yang harus dipenuhi sebagai syarat untuk mewujudkan kerukunan itu, dan semakin tinggi pula standar yang dapat menciptakan kerukunan tersebut, sehingga ketika kerukunan itu tercipta menjadi kerukunan yang utuh dan berkualitas.

Kerukunan itu menyumbang manfaat yang besar dalam menciptakan stabilitas nasional, menyukseskan pembangunan bangsa, menciptakan kedamaian dalam bermasyarakat, mempererat dan memelihara rasa persaudaraan, menciptakan rasa aman dan meminimalisir konflik atas nama agama. Hal-hal yang sering dipertentangkan oleh setiap umat beragama, baik inter agama maupun antar-agama semestinya mulai disadari dan dihindari agar tidak menimbulkan konflik. Pemerintah sebagai penjamin terwujudnya kerukunan umat beragama agar tetap konsisten pada pendiriannya, tidak ikut lebih jauh dalam urusan agama yang bersifat hak-hak umat beragama yang tidak dapat dibatasi (non-derogable rights), demikian juga terhadap hak-hak umat yang dapat dibatasi (derogable rights) tetap memperhatikan pembatasan-pembatasan yang telah diatur oleh undang-undang dengan tujuan untuk menjamin pengakuan dan penghormatan terhadap hak dan kebebasan orang lain, memenuhi tuntutan moralitas yang adil, ketertiban umum, dan kesejahteraan umum dalam suatu masyarakat demokratis.

\section{Kesimpulan}

Peran tokoh lintas agama dalam mewujudkan kerukunan umat beragama di Kota Malang ada tiga yaitu mengantisipasi konflik agar tidak terjadi, menyelesaiakan konflik agar tidak membesar, dan memelihara kerukunan umat beragama yang sudah tercipta, hal tersebut dilakukan dengan berbagai cara seperti berdialog, silaturrahim dan gotong royong. Peran tokoh lintas agama tanpak sangat penting agar kerukunan umat beragama tersebut dapat terawat selamanya.

Tokoh lintas agama Kota Malang memaknai kerukunan umat beragama itu dengan toleransi, saling memahami, saling menghormati, tidak ada konflik, damai, harmonis, tenang, nyaman dan tenggang rasa, tidak mengganggu dan mencemooh umat dan atau agama lain dalam 
melaksanakan aktifitas keagamaan masing-masing, dan tidak memaksakan kehendak. Dengan kata lain, kerukunan itu tidak dalam hal keyakinan (aqidah) akan tetapi ada dalam ranah amal sosial kemanusiaan (mu'amalah) karena keyakinan masing-masing penganut agama memiliki perbedaan, maka perbedaan agama atau keyakinan tidak boleh diperdebatkan atau dipaksakan untuk disatukan.

\section{Daftar Pustaka}

Adnan Buyung Nasution, A. Patra M. Zen. Instrumen Internasional Pokok Hak Asasi Manusia. Jakarta: Yayasan Obor Indonesia, 2006.

Agama, Kementrian. Laporan Tahunan Demografi Penganut Agama di Jawa Timur. Jakarta, 2014.

Aisyah, Siti, "Peran Tokoh Agama dalam Membina Kerukunan antar Umat Beragama Di Kawasan Pacinan Kota Semarang." Skripsi: Fakultas Ushuluddin Institut Agama Islam Negeri Walisongo, 2014.

Anang Firdaus, Muhammad, "Eksistensi FKUB dalam Memelihara Kerukunan Umat Beragama di Indonesia", Kontekstualita; Jurnal Penelitian Sosial Keagamaan, Volume 29, Nomor 1, 2014.

Bajera, Pdt. Ida Bagus, wawancara oleh M. Ikhwan. Wawancara dengan Tokoh Agama Hindu Kota Malang (9 Februari 2018).

Bertens, K. Sejarah Filsafat Kontemporer Jerman dan Inggris. Jakarta: PT Gramedia Pustaka Utama, 2014.

Bungin, Burhan. Metode Penelitian Kualitatif, Aktualisasi Metodologis ke Arah Ragam Varian Kontemporer. Jakarta: Rajawali Press, 2011.

Creswell, Jhon. Perencanaan, Pelaksanaan, dan Evaluasi Riset Kualitatif dan Kuantitatif. Yogyakarta: Pustaka Pelajar, 2015.

Handianoto dan Soehargo, Paulus H. Perkembangan Kota dan Arsiterktur Kolonial di Malang.Surabaya-Yogyakarta. Lembaga Penelitian dan Pengabdian Kepada Masyarakat Univ. Kristen Petra dan Penerbit Andi, 1996

Hariono, wawancara oleh M. Ikhwan. Wawancara dengan Tokoh Agama Budha Kota Malang (11 Februari 2018). 
Ikhwan, M. Belajar Multikultural Dari Kota Malang, Yogyakarta: Zahir Publishing, 2019.

Indonesia, Majelis Permusyawaratan Rakyat Republik. Undang-Undang Dasar Negara Republik Indonesia Tahun 1945. Jakarta: Sekretariat Jendral MPR RI, 2019.

Jirhanuddin, Perbandingan Agama Pengantar Studi Memahami AgamaAgama, Yogyakarta: Pustaka Pelajar 2010.

Kaharuddin, Muh. Darwis, "Peran Forum Kerukunan Umat Beragama (FKUB) dalam Pembinaan Kerukunan Hidup Beragama di Luwu Timur", PALITA: Journal of Social-Religion Reseach, Volume 4, Nomor 1, 2019.

Kususma, Taufik, wawancara oleh M. Ikhwan. Wawancara dengan Tokoh Agama Islam Kota Malang (10 Februari 2018).

M. Thoriqul Huda, Irma Khasanah, "Peran Budaya dalam Membangun Hubungan Antara Umat Beragama di Suku Tengger", PALITA: Journal of Social-Religion Reseach, Volume 14, Nomor 1, 2019.

Mujab, M., wawancara oleh M. Ikhwan. Wawancara dengan Tokoh Agama Islam Kota Malang (10 Februari 2018).

Mulyo, Bintarto, wawancara oleh M. Ikhwan. Wawanara dengan Tokoh Agama Konghucu Kota Malang (15 Februari 2018).

Nursalim, wawancara oleh M. Ikhwan. Wawancara dengan Tokoh Agama Islam Kota Malang (13 Februari 2018).

Prayitno, Stefanus Hadi, wawancara oleh M. Ikhwan. Wawanara dengan Tokoh Agama Kristen Kota Malang (4 Maret 2018).

Rahmadi, A. Sulaeman, "Peran Kaum Muslimin Dalam Pembinaan Kerukunan Hidup Antarumat Beragama Di Kota Surakarta (Studi Di Fkub Kota Surakarta)." Tesis: Universitas Muhammadiyah Surakarta, 2012.

Rizvi, Ali A. Sang Muslim Ateis: Perjalanan dari Religi ke Akal Budi. Jakarta: LSM Indeks, 2017.

Rodin, Dede, "Riddah dan Kebebasan Beragama Dalam Alquran" Ahkam: Jurnal Ilmu Syariah, Volume 14, Nomor 2 Juli 2014. 
Stev Koresy Rumangit. "Kekerasan dan Diskriminasi antar Umat Beragama di Indonesia", Lex Administratum: Jurnal Elektronik Bagian Hukum Administrasi Negara Fakultas Hukum Unsrat, Volume 1, Nomor 2, 2013.

Sudarsyah, Asep, "Kerangka Analisis Data Fenomenologi (contoh analisis teks sebuah catatan harian)." Jurnal Penelitian Pendidikan (JPP): Universitas Pendidikan Indonesia, 2016.

Sugiwijono, Nugroho, wawancara oleh M. Ikhwan. Wawancara dengan Tokoh Agama Katolik Kota Malang (13 Februari 2018).

Sumbulah, Umi, "Pluralisme dan Kerukunan Umat Beragama Perspektif Elit Agama di Kota Malang”, Analisa: Journal of Social, Science and Religion, Volume 22, Nomor 1, 2015.

Titik Suwaryati, Imam Syaukani, Kompilasi Kebijakan dan Peraturan Perundang-Undangan Kerukunan Umat Beragama. Jakarta: Puslitbang Kehidupan Keagamaan, 2008.

Wahidi, Ahmad, "Mistisisme Sebagai Jembatan Menuju Kerukunan Umat Beragama", Ulul Albab: Jurnal Studi Islam, Volume 14, Nomor 2, 2013.

https://bakesbangpol.malangkota.go.id/2019/12/11/kota-malang-raihpenghargaan-kota-peduli-ham-2019/

https://malangvoice.com/malang-raih-penghargaan-kota-peduli-ham-tahun2018/

https://suryamalang.tribunnews.com/2017/05/15/m-anton-kota-malangminiaturnya-indonesia-kami-menjaganya-supaya-tetap-damai-dan$\underline{\text { rukun }}$

https://www.koran-jakarta.com/kota-malang--hattrick--raih-penghargaanpeduli-ham/

https://www.liputan6.com/regional/read/2575667/masjid-dan-gerejabersanding-mesra-di-malang

https://www.timesindonesia.co.id/read/news/140290/komnas-ham-kasusintoleransi-terus-meningkat 
https://www.tribunnews.com/regional/2015/07/18/di-kota-malangtoleransi-antar-umat-beragama-telah-berlangsung-lama 